\title{
Effect of Fiscal Policy on Human Capital in Thailand
}

\author{
Submitted 12/12/20, $1^{\text {st }}$ revision $23 / 01 / 21,2^{\text {nd }}$ revision $27 / 02 / 21$, accepted $20 / 03 / 21$
}

\section{Sakchai Naknok ${ }^{1}$}

Abstract:

Purpose: The purpose of this study aims to examine the composition effect of fiscal policy variables, labor effectiveness, Thailand's innovation, public debt, and personal income on human capital.

Design/Methodology/Approach: To achieve this purpose, regression models are used, with time series data, employed form 1985 to 2019. The simple model was employed to investigate the effect of fiscal policy and personal income toward both long-run and shortrun human capital.

Findings: The results found that in the long run after changing fiscal policy, labor effectiveness, Thailand's innovation, and personal income are positive coefficient and significant for human capital while public debt has a negative coefficient and is significant for human capital in Thailand. Only public debt and personal income are short run significant of human capital accumulation.

Practical Implication: Based on the finding of this study, it recommended that appropriate fiscal policy is still worthwhile and fiscal policy authorities must use an effective framework to build the education system in order to improve human capital in Thailand.

Originality/Value: Because of this finding, indicating how the effective roles both policy maker and lecturer in university including education pattern should be shaped and reformed. This finding will be the track to enhance labor performance in the long-term human capital and all part of involvement will be aware the future developing target of country in order to ultimately obtain the highest successful not only in Thailand's labor bot also throughout the world particularly in developing countries..

Keywords: Human capital, fiscal policy, eucation reform, labor performance, Thailand.

JEL Codes: E24, O15, O23.

Paper type: Research article.

Acknowledgement: The author would like to acknowledge the Faculty of Management Science, Valaya Alongkorn Rajabhat University under the Royal Patronage for research facilitation from the beginning through to the completion of this article. This research did not receive any specific grant from any funding agencies.

\footnotetext{
${ }^{1}$ Faculty of Management Sciences, Department of Economics, Valaya Alongkorn Rajabhat University under the Royal Patronage, Klong-Nueng, Klong-Luang, Thailand.

E-mail: sakchai_nak@hotmail.com
} 


\section{Introduction}

The main premise of the human capital development approach is expanding peoples both the key to country development and the significant contribution to economic growth that means for sustainable economic development. The human development policy is central to approaching the facts on inequalities and development in human capital and proposing ideas to accurately act on them over the $21^{\text {st }}$ century (UNDP 2019). The right policy mix and institutional arrangements can create benefits that are shaped broadly into human capital in the long run economic success and labor market. Indeed, the economic growth of recent decades has been accomplished through increasing consumption and production patterns.

Developing countries must continue to raise their people's living standards and eradicate poverty by containing increases in their human capital. This is a huge challenge with a goal of prosperity and sustainable development. In Thailand, Thai workforce is relatively low because there are many factors including an unskilled labor, delayed technological and innovation development, and problems about personal income. Such challenges can pose limitations to the country's competitiveness development and economic growth, as well as income generation and improvement to the well-being of the Thai people. It is clear in terms of human capital enhancement that improvement of the education system agenda should be pushed in this process in order to provide a foundation for the shift in the Thai workforce's development, intensive competitiveness toward workforce development or human capital, and sustainable lifestyles.

According to a general concept of human capital, it consists of the abilities, skills, and talents that are gained by an individual through the education system and getting experience (Goldin, 2016). Education through the formal schooling system plays an essential role in obtaining the full components of human capital. While this change will not happen in the short run, the education sector has a critical role to play in imparting the knowledge and skills that lead to labor skills change for sustainable development. A sustainably developed agenda of education highlights promising practices in formal and informal education contexts that have the potential to change business and education patterns. In addition, economic development, human capital accumulation, and poverty reduction depend upon education development through appropriate fiscal policies using annual government expenditure as a tool. Fiscal policy involves the management of the annual money spending.

The long-term patterns of education development in Thailand and the conditions of sustainable development were characterized by certain major macro-economic variables, in particular those underpinned by labor developments, work patterns, and schooling systems. It is the main purpose of this paper. Labor productivity is an important economic indicator that is certainly measured to economic growth, trading competitiveness, and living standards within an economy. 
Labor productivity represents the total volume of output (measured in terms of GDP) produced per unit of labor (measured in terms of the number of employed persons) during a given time reference period. Moreover, gross domestic product (GDP) to labor input per unit level indicates general information about the effectiveness and quality of human capital in the production process. Therefore, under the limitations imposed by the fundamental factors for all aspects of a country's development within a global trend where technology is developing rapidly, many countries are swiftly developing innovations to elevate their productivity. Thailand faces a severe challenge to accelerate the development of various fundamental policy factors. These factors, governmental policies, should play a constructive role in developing science, technology, and innovation in order to enhance efficient human resource development. So, strengthening government policies is a key to incorporating creativity to generate a new valued-added human capital, including manufacturing processes, new products, technology changes, business patterns, and human capital enhancement (Office of the National Economic and Social Development Council, 2019)

With such a variety of challenges, human capital should be developed in the capacity by governmental policy via the education system to achieve quality education, learning, and skills enhancement, and through improved environmental standards of strengthening the economy. However, Overall, policy makers play an active role in promoting the development and use of new breakthrough technologies to reach future labor market goals. Effective governmental policies can create and perfectly shape markets, rather than merely fix them. Especially for education institutions, needs to be strengthened in order to enhance future workforce ability to participate in the development of the nation's human capital, which in turn can help to drive sustainable development in Thailand more successfully (Office of the National Economic and Social Development Council, 2019).

Due to these significant problems, a major country transformation has affected the labor regime. Clearly, it is important to confirm that the labor regime is not only the result of labor development between industries subject to economic growth but also the combination of the major parts of the fundamental structure, especially in a developing country such as Thailand. If the fiscal policies fully play a part to improve labor standards over the long term on increasing overall productivity, it could be thereby boost per capita income for Thai people of all ages as perfected labor and the ability to drive the country forward the long-term more successful.

\section{Literature Review}

In the state of workforce development efforts, there are many factors contributing to the increased expectation for schooling performance to play an important role in human capital accumulation. It has been clearly identified that colleges are key to developing the skilled workforce necessary to respond to industry needs. The higher education system in Thailand was set up by the central policies of the university 
education system. Generally, the higher education or education level as human capital of labor and government expenditure are the main essential factors that cause more economic development.

\subsection{Education Level as Human Capital}

The importance of education level in the growth process can be traced back to its validation by Adam Smith and Alfred Marshall, and human capital is measured by average schooling years and rate of return on productivity. That is, domestic educational system and shape increases with the level of human capital in effectively educated countries. Seclen-Luna et al. (2020) explored the effects of human capital composition on manufacturing firm performance. The results found that there is a positive relationship between human capital composition, workers' education level, and labor productivity in manufacturing firms. In addition, the resource-based theoretical perspective of human capital measured by number of highly education workers is an important role in innovation in more developed areas (Sun et al., 2020).

The Ministry of Education (MOE) is the main agency responsible for promoting the provision of education at all levels, both basic and higher education. Higher education, offered in universities and colleges in many areas of Thailand, is provided at a diploma or associate degree level, and degree levels, ranging from bachelor's degrees to doctoral degrees. Within a responsibility to the labor market demand to create an accurate labor performance, the national education development policy by the policy maker and MOE continuously attempts to enhance the quality of education, especially on improving cognitive skills that enable individuals to learn problem solving and also create appropriate labor shape by using a new teaching pattern, productive learning (Ministry of Education, Thailand, 2017).

Quality of education, in particular higher education, is generally perceived as a major determination in economic growth and development of labor performance and human capital. Liu (2017) found that the structure of the higher education system affected both human capital and expanding product variety. Liu still confirmed that the diversification of the education system offered at higher education level is the most suitable way to produce high performance of labor as more human capital. Therefore, education of state policy has been the main contributor to the building of a stable education system and the extension of educational possibilities. When an inequality in educational opportunities is decreasing, this situation is mostly based on a continuous increase in the completion of the education cycles and higher education. It is to bring out the main macroeconomic variables of the economic development sustainability and educational advance.

Thus, it can be confirmed that education level has been regarded as one of the 
leading determinations of education expenditure by fiscal policy on the economic growth and human capital. It has led government policy of many developing countries to invest in the education sector. It is pointed out that, in increasing returns and long-term growth, education and knowledge have a positive human capital effect. Therefore, education level and pattern by fiscal policy is the main engine for driving human capital and economic growth. And the formation of a large performance of human capital is a driving force for a country's rapid economic change in many ways.

\subsection{Government Expenditure}

Fiscal policy, government spending, can be a useful economic policy tool for government mechanism to influence an economy. Increased government spending leads to increased production and faster economic recovery. Thailand is continually strengthened by increased education spending to improve education development and economic growth. Furthermore, expenditure on education mainly results in the achievement of the higher educational structure, with better quality of students, and more labor ability. The structural indicators of education development have mainly been measured by the student ability level and the increases in public expenditure on education, both private and public, in investment distribution, and social mobility investment (Sandrine, 2015). The long-term context for the development of education has been the key structure of economic growth. Public expenditure on education, annual state budgets, is thus tied to economic prosperity. Government expenditure in the educational budget has provided the means for the development of education leading to workforce performance development. In these circumstances, the amount of public expenditure on education makes it a structural component of growth.

Consequently, the extension of access to better education makes any additional skill need and increasingly dependent on the strength of growth and worker ability. For these reasons, the importance of the sustainability of public policy, the state budget on education seems unavoidable by given the undeniable quantitative schooling achievements. The numerous benefits arising from education have been considered a consensual expenditure issue of policy makers. Education has been recognized as a key macroeconomic factor of economic growth and labor development. The strength of education upgrading as an essential development goal has reached public policy.

Because of these, the public sector has increasingly been focusing on education expenditure sufficiency. The lack of efficiency in public education spending has been the barrier to put forward the low education achievement in Latin American countries (ECLAC, 2015). Government expenditure theories are classified in order to increase state activities or gross domestic product (GDP) and also to cause the crowding-in or crowding-out effect of private investments. The concept of crowding-out is used to assess the impact of government spending on private 
investment in a country (Usman, 2015). The crowding-out phenomenon happens when there is an increase in government spending but it has significantly negative affects the economic growth on either the demand or supply side. So, the increase in economic activities that were measured by full employment level in the country must rises faster than the proportional increase in government expenditure. This results in a relatively highly effective expansion of the public sector expenditure. Most importantly, government expenditure towards economic-stimulating expenditure such as public investment may have played a crucial role in enhancing state activities and structural transformation, as well as in shaping sustainable country's development (Armstrong, 2018).

\subsection{Technological Investment as Innovation}

Technological development and innovation have long been understood as a fundamental factor in country's development and labor performance accumulation. Both economists and other social scientists have examined the effects of innovation on economic growth, the factors associated with the production of innovations including human capital accumulation, and the geographic distribution of innovations. The first indicator of technological progress comes from creating new products and processes. The second indicator of technological progress is adaption of technologies developed elsewhere in the country. Technological development is considered to point to the fundamental structure of a country's growth and that is related to technological investment for the country.

Within the technology development target, fiscal policy to relying on the country's labor performance and natural resources, Thailand has increased in science and innovation spending responding to real labor market and entrepreneur needs by motivating people and supporting funds in order to increase the number of graduates, lecturers, and personnel abilities (Office of the National Economic and Social Development Council, 2019). However, technological development as innovation is considered as the driving force for economic growth, labor inputs, and total factor productivity (TFP). If there is no continuous improvement of technology in TFP in a country, there cannot be long-term sustainable growth of the economy.

Jin and Tao (2015) agreed that the government should constantly adjust its economic structure and promote economic growth through structural optimization and technology reform. There is no denying that technological progresses have created positive changes. Inventions such as computers, the Internet, communications satellites, and genetic diagnostic tools help improve our lives in many ways. Huang and Liu (2017) argued that with rapid changes around the world, workers should continuously learn the path of needs in economic growth with efficient human capital as part of the working process to ensure long-term success.

Many developing countries fail to use technologies that would significantly pose a problem to increase production of in terms of labor skill. Seclen-Luna et al. (2020) 
pointed out the importance of labor absorptive capacity in adopting frontier technologies. They found that the implementation of modern management practices, revolving around composition on production, total quality management, and employee productivity, significantly increased the productivity of firms. In addition, they concluded that technological development and practices are the real issues involved in increasing their labor productivity in modern both product and service companies.

Technological development as innovation is considered as the driving force for economic growth, labor inputs, and total factor productivity (TFP). If there is no continuous improvement of technology in TFP in a country, there cannot be longterm sustainable growth of the economy. Zhao (2014) pointed out that in order to solve the deep-rooted contradictions in economic development, countries must change the means of development by pushing economic development through technological innovation and enhancement of the workers' performance, as well as the improvement of the combination of such countries' output elements. Gan and Zheng (2011) confirmed that the rationalization of economic growth causes from the advancement of industrial structure and worker effectiveness.

Jin and Tao (2015) agreed that the government should constantly adjust its economic structure and promote economic growth through structural optimization and technology reform. There is no denying that technological progresses have created positive changes. Inventions such as computers, the Internet, communications satellites, and genetic diagnostic tools help improve our lives in many ways. Huang and Liu (2015) argued that with rapid changes around the world, workers should continuously learn the path of needs in economic growth with efficient human capital as part of the working process to ensure long-term success. For example, high-skilled workers might be better attribute about frontier technologies and about how those technologies could be useful for future business purposes, which are important steps for adopting a new technology. Because of this, the author would like to explore the relationship between human capital and technological investment as innovation in order to manage workforce strategy to increase productivity with highly qualified output across industries.

\subsection{Human Capital Enhancement}

Regional disparities in real output, employment, and productivity in developing economies have been driven by growing private and public consumption with robust infrastructure investment and accommodative monetary and fiscal policies. In Thailand, the government looks forward to supporting industries in the dynamic and changing business circumstances not only on implementing technology investment for better productivity but also in the beneficial process of fiscal policy optimization and human capital improvement.

The impetus of the public investment is the tremendous power of human capital 
improvement for continuously developing productive labor force. The economic relationship between productivity and public capital is the main factor of individual labor performance to provide labor force for the society especially on industry's need (Rong, 2020). The profound understanding of the relationship between human capital composition, innovation investment focusing on education system by public policy and labor attribute of manufacturing firms positively affects labor productivity. Hence, individual labor performance can help human resource managers to push their job position according to educational level and skill of human capital. This could require that not only human resource management innovates, but also that innovative skill be developed with educational establishments to boost training towards product and service innovation (SeclenLuna et al., 2020).

The Thai government invests in innovation such as internet and broadband service demands across various sectors, and there will be a rise in government spending in the coming years. Public investments are still ongoing; therefore, fiscal deficit will continue in the future. The government can still deploy deficit fiscal policy to activate the momentum of economic growth and change in the coming years. Additionally, regarding the future of jobs skills across industries, many companies choose to differentiate and locate specific job roles and economic activities in different business needs depending upon specific labor due to a range of specific skills of labor considerations. For this reason, policy makers should prioritize fiscal policy emphasizing tertiary education to improve human capital for industrial disparity and economic growth.

Dimov (2017) investigates a qualitative understanding of human capital in entrepreneurship. He found that the conceptualization and skill of human capital in entrepreneurship have been widely and consistently used to predict and cope challenging outcomes such as engaging in venturing efforts, venturing progress, and venture emergence, performance, and survival. It is clear that the logic or appropriateness of current approaches to measuring human capital is the high challenges to governments and institutions to provide quality and relevant education within countries and the practice of making effective human capital available to the mass market, and diversification policies on tertiary education, are important on the agendas within many countries, especially developing ones in order to push forward sustainable economy. Because of this, most governmental policies have established and invested in human capital by cross-border tertiary education. The core of macroeconomic tools is that an accurate fiscal policy can be capable of stimulating aggregate demand, reviving a recession economy, and promoting economic growth.

According to $\mathrm{Yu}$, Zhu, and Baležentis, (2017) confirmed that education development is a critical component for a modern economy as the illiteracy rate and is created over the long run by a labor force that possesses the performance to work and produce, and by entrepreneurs who have incentives to invest in capital stock. 
In macroeconomic theory, economic growth is an increase in the production of economic goods and services. An increasing production refers to activities involved creating a product. Fiscal policy has an important role to play in supporting growth and recovery and also contributes to productivity and complements the private sector by improve human capital. Finally, increases in public investment would have overall positive effects on factor productivity and output and ultimate economic growth. A country's policy makers should emphasize government expenditure that can influence its overall economic performance on long-term labor development as human capital enhancement.

\subsection{Public Debt}

The relation of public debt effecting economic growth has become the crucial issue of countries, especially for policy makers who have to effectively manage increasing fiscal imbalance. In terms of economic theory, public debt can directly influence economic growth through the transmission channels of human capital accumulation and total factor productivity (TFP). Meanwhile, an indirect channel of economic growth, the change of labor forces, tends to have indirect effect to the growth, which implies that when the economy is full employment because the public debt involves the available capital in the market. Onafowora and Owoye, (2019) pointed out that domestic investment has significantly positive effects on economic growth and human capital development, while higher public debt hampered growth. From this results, in order to obtain highest destination, they also suggested that government may need to adopt effectively managing performance of public debt as a major policy and intensify efforts at utilizing loans obtained capital projects. Managing performance of public debt may have direct positive net destination value but, to secure strong and inclusive growth.

These strategies must be linked to policy makers that enhance economic stability and the quality of their institutions including encourage capital inflows and domestic investments, trade earnings, and human capital accumulation. Because of these, many developing countries are currently seeking to look for their own development through a set of processes, policies, and practices. A national development plan will be the priority that dictates core sector targets contributing to the best framework for development of needs that promote effective industries to reach higher development and goals. The successful results have implications not only for how countries respond to the sustainable development goals (SDGs) but also in terms of the global and local challenges that these countries confront. Thus, the government would issue public debt to cover the deficit by remaining country development plan. Most of all, when the economy is not full employment, part of the capital in the market responding to the national development plan remains available for the private sectors.

The TFP channel is calculated by dividing output by the weighted average of labor and capital as input for generating long-run economic growth. Teles and Mussolini 
(2014) supports the effect of debt on the economic growth by using channels of productivity and considered the fiscal policy on public debt in order to contributing improvement of TFP. Abubakar, and Mamman, (2020) sought the effect of public debt on economic growth into the short run and long run effect on the economic growth of The Organization for Economic Co-operation and Development (OECD) countries. The results showed the presence of a positive short run effect and negative long run effect of public debt on the economic growth of OECD countries.

In contrast to this view is the argument that public debt has a neutral effect on economic growth that can help to develop an economy by expanding the knowledge and skills of human capital in the country. This is premised upon the view that when the government borrows and channels the funds towards economic stimulating expenditure such as public investment, this leads to an increase in economic growth (Armstrong, 2019). When investment is inadequate to ensure the attainment of full employment, borrowing and spending by the government leads to an increase in public investment which complements the inadequate private investment to stimulate economic growth and recover. Moreover, Tahir et al. (2020) examined that human capital, trade openness and public investment are positively associated with economic growth for developing countries. The study also revealed that human capital accumulation has positively impacted economic growth. Finally, domestic investment and employment level appeared to be the main growth determinants and economic recovered successes in developing countries.

\subsection{Personal Income}

Low-income countries (LICs) and developing countries face a number of economic challenges. These challenges have been effected by the interruption of the country's development in many ways. All challenges have been made deterrent by the options of policy makers. These factors are putting at risk the successes achieved in economic growth and poverty reduction. The government and policy makers in these countries face difficult options and trade-offs to still maintain the fiscal sustainability of the country. Kennedy et al. (2017) confirmed in this issue, they identified that accurate policy makers can address rising income inequality by implementing measures that support and enhance on human capital accumulation given its long-run economic and sustainable development. Moreover, human capital facilitates long-term country' s development because aggregate demand for labor of industry needs is positively associated with knowledge diversification; correlates positively with high levels of income; correlates positively with economic growth; and finally subsumes the impact of human capital on growth (Mthanti and Ojah, 2017).

In Thailand, the Thai Ministry of Finance (MOF) and the Bureau of State Budget (BOB) have met this challenge to recover balance of budget by using fiscal policies and budget management tools to revise government expenditure in order to increase disposable revenues and the country's competitiveness of future long-term 
obligation. The government expenditure is to create medium and long-term stimulus for economic recovery. The main objective is to encourage and build up Thailand's economic capability and competitiveness in many ways in order to survive the global economic crisis and to achieve poverty reduction from the world economy challenges. The fiscal policy measures, comprising income transfer and lowering costs of living, should effectively stimulate the economy in terms of full employment including higher labor abilities and attributes. Disposable income of people has increased due to income transfer, reduction of living costs and improving labor abilities.

More recent study, Gensowski (2018) investigates the effect of personality attributes and cognitive abilities on lifelong income. The study found that cognitive abilities have significantly and positively on income increase. A common response by governments to these challenges has been to make their main priority the necessity of national development planning to build institutions' capacity, economic opportunities, poverty reduction, higher income per capita, human resources, and risk management capabilities, as well as an improvement in living standards that are needed to achieve national development. One of the main country's objectives on fiscal policy is innovation and education quality that has been recognized as key to the modernization of economies leading to positively associated with GDP per capita.

\section{Objective of Research}

As discussed in the review of literature, human capital is a core essential in developing countries by measuring of the skills, capacity and attributes of labor. This paper aims to analyze the effect of government policies on human capital accumulation in Thailand. The quantitative research is to validate the relationship in the long and short run between fiscal policy, personal income, and human capital in order to find out which policy effectively influenced human capital in Thailand by using the 35 years of data.

\section{Method and Data}

The main focus of this research is to explore the effect of the independent on the dependent variables. Regression analysis was used to determine the cause and effect between the dependent and independent variables. The research used a simple model on the effect of fiscal policy and personal income toward human capital in Thailand. In the simple model, there is no control variable involved in the model specification. The simple model is preliminary analysis in order to explore the association and its significance between fiscal policy including personal income toward human capital. The literature review contributes views on how different perspectives of fiscal policy affects human capital. The modeling of fiscal policy was carried out to identify which of these economic variables affect human capital. This could help guide this study on modeling the regression model to be applied in 
this research. This method is used where the investigator manipulates the variables being studied to ascertain how the overall model reacts to changes in variables within the model. This research employed secondary annual statistics covering 1985 to 2019 , a period of 35 years for each variable. The reason for this selection data of the time period is consideration for availability, which is the major combination in any empirical investigation.

The model examines the composition effect of labor effectiveness, innovation, public debt, and personal income on human capital in Thailand.

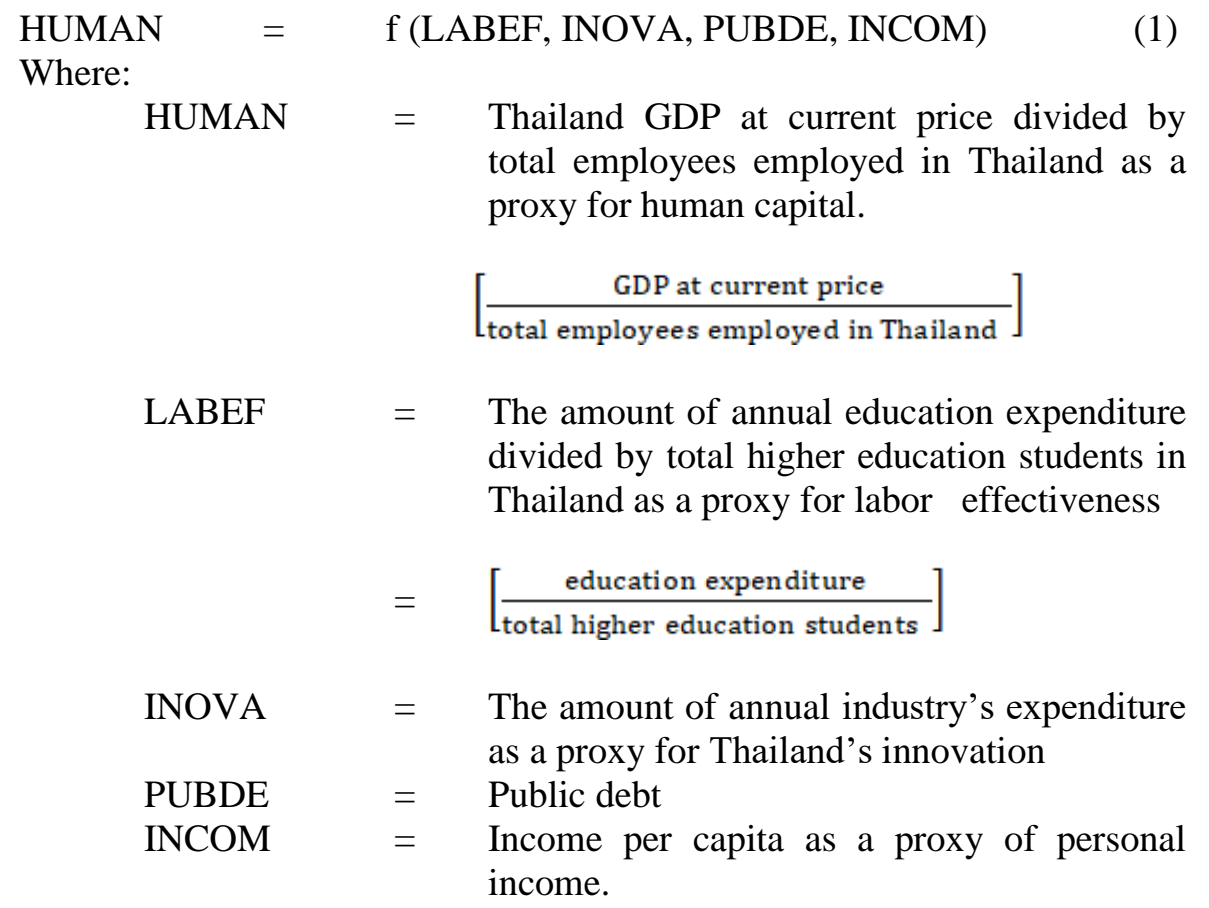

\subsection{Variables and Data}

The key variables on interest are labor effectiveness, Thailand's innovation, public debt, personal income, and human capital. The researcher gathered the data source and description of variables of determination toward human capital and also human capital to minimizing endogenous variables. Table 1 summarized the variables description and data source.

Table 1. Variables description and data source

\begin{tabular}{|l|l|l|l|}
\hline Variable & Indicator & \multicolumn{1}{|c|}{ Description } & \multicolumn{1}{c|}{ Source } \\
\hline HUMAN & $\begin{array}{l}\text { Human } \\
\text { capital }\end{array}$ & $\begin{array}{l}\text { Human capital is important for the country's } \\
\text { development because it is perceived to } \\
\text { increase productivity and output. Human } \\
\text { capital is c omputed by dividing GDP by the }\end{array}$ & $\begin{array}{l}\text { 2. Ministry } \\
\text { of Labor }\end{array}$ \\
\hline
\end{tabular}




\begin{tabular}{|c|c|c|c|}
\hline Variable & Indicator & $\begin{array}{r}\text { Description } \\
\end{array}$ & Source \\
\hline & & $\begin{array}{l}\text { number of workers. GDP to labor input per } \\
\text { unit level indicates general information about } \\
\text { the effectiveness and quality of human capital. }\end{array}$ & \\
\hline LABEF & $\begin{array}{l}\text { Labor } \\
\text { effectiveness }\end{array}$ & $\begin{array}{l}\text { Labor effectiveness refers to a highly skilled } \\
\text { and labor force that responds quickly to } \\
\text { changing business needs. Education has a } \\
\text { multiplier effect, increasing labor force } \\
\text { participation. Labor effectiveness is computed } \\
\text { by dividing total education expenditure by the } \\
\text { higher education students (in university). }\end{array}$ & $\begin{array}{l}\text { 1. Bureau of } \\
\text { the Budget } \\
\text { 2. Ministry } \\
\text { of Education }\end{array}$ \\
\hline INOVA & $\begin{array}{l}\text { Thailand's } \\
\text { innovation }\end{array}$ & $\begin{array}{l}\text { Innovation is an increase in labor effectiveness } \\
\text { that encourages an increase in innovation } \\
\text { investment in the country. Innovations have } \\
\text { been recognized as key to the increasing of } \\
\text { labor abilities or human capital. }\end{array}$ & $\begin{array}{l}\text { 1. NESDC } \\
\text { 2. Ministry } \\
\text { of Science } \\
\text { and } \\
\text { Technology }\end{array}$ \\
\hline PUBDE & Public debt & $\begin{array}{l}\text { Public debt can directly influence the } \\
\text { economic growth destination of a country. An } \\
\text { increase in government spending mostly } \\
\text { comes from public debt in order to obtain of } \\
\text { national development planning including labor } \\
\text { performance. }\end{array}$ & $\begin{array}{l}\text { 1. NESDC } \\
\text { 2. Ministry } \\
\text { of Finance }\end{array}$ \\
\hline INCOM & $\begin{array}{l}\text { Personal } \\
\text { income }\end{array}$ & $\begin{array}{l}\text { Personal income refers to an individual's total } \\
\text { earnings. People were classified according to } \\
\text { their employment status by answering a } \\
\text { question relating to their main activity. One } \\
\text { distinguished reasons is paid employed. }\end{array}$ & NESDC \\
\hline
\end{tabular}

Note: NESDC stands for Office of the National Economic and Social Development Council.

Source: Own study.

The data used in this study was time-series data. This type of data was applied on ordinary least squares (OLS) regression to estimate the parameters of the variables. The research also applied time-series unit root tests in establishing the time-series properties of the data. The co-integration test was used to test the long-run relation among the variables, and then error correction model (ECM) regression was used to estimate both short-term and long-term effects of time-series data. ECM is a theoretically driven approach useful for directly estimating the speed at which a dependent variable returns to equilibrium after a change in independent variables. The term error correction relates to the fact that last-period's deviation from a longrun equilibrium, the error, influences its short-run dynamics.

\subsection{Unit Root Test}

In the testing of time-series data in regression analysis, the econometric analysis of these data is necessary to begin identifying the order of integration to confirm the presence of a unit root test for the individual variables to establish the stationary and non-stationary nature of time-series data in order to avoid spurious regression. Thus, 
these variables must be stationary. The research employed the Augmented DickeyFuller (ADF) unit root test. The ADF test is conducted using the regression of the form:

$$
\begin{aligned}
& \text { Consider } \Delta \mathrm{Yt} \sim \mathrm{I}(\mathrm{d}) \\
& \Delta \mathrm{Y}_{\mathrm{t}}=\alpha+\beta \mathrm{t}+\theta \mathrm{Y}_{\mathrm{t} 1}+\sum_{i=1}^{\mathrm{p}} \beta_{\mathrm{i}} \Delta \mathrm{Y}_{\mathrm{ti}}+\varepsilon_{t} \quad \text { (intercept and trend) }
\end{aligned}
$$

\subsection{Co-Integration Test}

Another technique employed in this research was the co-integration method. This technique was adopted to establish whether two or more time-series variables have a long-run relationship among themselves. Unless the time-series variables can be demonstrated to be co-integrated, using non-stationary data may cause a problem of spurious regression. Therefore, Engle and Granger (1987) developed co-integration as an econometric test of the relationship among non-stationary time-series variables. The theory of co-integration is that two or more variables under consideration must have the same order or integration $\mathrm{I}(\mathrm{d})$ in order to qualify as non-stationary.

Asymptotically, the test is independent of which variable occurs on the left-hand side of the co-integrating regression. Interchanging the position of all variables in the co-integrating equation to the right-hand from the left-hand side yields super consistent estimates of the parameters; implicitly you are assuming that the normalization corresponds to some long-run economic meaningful relationship.

\subsection{Error Correction Model Estimation}

From the Engle and Granger (1987) theorem, if a set of variables are found to have co-integrating vectors, then there exists an error correction of the data. A suitable estimation technique, a vector error correction model (VECM), was estimated to both short-run changes in variables and deviations from equilibrium. An annual data estimation approach and in order not to lose degrees of freedom, the number of lags is typically small, one or two lags is appropriate for annual data (Wooldridge 2016). In this research, lag length criteria also suggest the chosen of two lag for estimating the VECM. The researcher generated an error correction representation of the form:

$$
\begin{aligned}
& \text { DLHUMAN }=\beta_{0}+\sum_{i=1}^{p} \beta_{1 i} \text { ALHUMAN }+\sum_{i=1}^{q} \beta_{2 i} \Delta \text { LLABEF }+ \\
& \sum_{i=1}^{q} \beta_{3 i} \Delta \text { LINOVA }+\sum_{i=1}^{q} \beta_{4 i} \Delta \text { LPUBDE }+\sum_{i=1}^{q} \beta_{5 i} \Delta \text { LINCOM }+\lambda \text { ECT }_{\mathrm{t}-1}+\varepsilon_{\mathrm{t}}
\end{aligned}
$$

Where HUMAN = human capital, LABEF = labor effectiveness, INOVA = Thailand's innovation, PUBDE = public debt, INCOM = personal income, and L = natural $\log$. The essence of the natural $\log$ transformation is to reduce a tenfold difference in value of the variables to twofold. It also allows the researcher to interpret the coefficient of variables as direct elasticity. Equation (3) represents the operation form of the generalized ECM with $\beta_{1}$ to $\beta_{5}$ as short-run coefficients and 
$\lambda \mathrm{ECT}_{\mathrm{t}-1}$ constituting the long-run representation in the model with $\lambda$ as the coefficient of error term.

Regression coefficients describe the relationship between a predictor variable and response variable. In linear regression, coefficients are the values that multiply the predictor values to response variable. The coefficient value represents the change in the response given a one-unit change in the predictor. Table 2 gives the expected sign coefficients and significance of the predictor variables, labor effectiveness, Thailand's innovation, public debt, and personal income to human capital.

Table 2. Expected sign coefficients of the regression

\begin{tabular}{|l|l|}
\hline \multicolumn{1}{|c|}{ Independent variables } & \multicolumn{1}{c|}{ Expected signs } \\
\hline Labor effectiveness & Positive $(+)$ \\
\hline Thailand's innovation & Positive $(+)$ \\
\hline Public debt & Positive $(+)$ \\
\hline Personal income & Positive (+) \\
\hline
\end{tabular}

Source: Own study.

The data is described in the correlation matrix in Table 3. Table 3 shows that LABEF is correlated very highly with the PUBDE and INCOM at the normal 5 percent level of significant. The positive relationship between PUBDE and INCOM implies that as LABEF increased with PUBDE and INCOM, respectively in Thailand. The correlation matrix result shown in Table 3.

Table 3. Correlation matrix of all variables

\begin{tabular}{|c|c|c|c|c|}
\hline LHUMAN & LLABEF & LINOVA & LPUBDE & LINCOM \\
\hline LLABEF & 1.0000 & & & \\
\hline LINOVA & 0.7236 & 1.0000 & & \\
\hline LPUBDE & 0.8012 & 0.6830 & 1.0000 & \\
\hline LINCOM & 0.9879 & 0.7430 & 0.7560 & 1.0000 \\
\hline
\end{tabular}

Source: Own study.

\section{Unit Root Test Results}

To avoid spurious regression, variables are often differenced to achieve stationary. The null hypothesis for this test requires that the coefficient of the auto-regressive parameter of the variable be equal to one and the alternate hypothesis states that it is less than one. The non-stationary is established using the ADF (Dickey and Fuller, 1981) test; the variables must be differenced (d) times to make them stationary and thus said to be integrated to the order (d). The variables are also tested for cointegration using the ADF (Dickey and Fuller, 1981) test, and if the variables are found to be co-integrated, an ECM is estimated with OLS generating without spurious results. The results of the ADF unit root test shown in Table 4. 
Table 4. Results of Augmented Dickey-Fuller unit root test

\begin{tabular}{|l|c|c|c|}
\hline \multicolumn{1}{|c|}{ Variable } & t-statistic & Critical Value 1\% & Results \\
\hline Log_HUMAN & -1.79277 & -3.639407 & Non-stationary \\
\hline$\Delta$ Log_HUMAN & -4.457832 & -3.711457 & Stationary \\
\hline Log_LABEF & -0.451544 & -3.639407 & Non-stationary \\
\hline$\Delta$ Log_LABEF & -5.867124 & -3.653730 & Stationary \\
\hline Log_INOVA & -2.224622 & -3.639407 & Non-stationary \\
\hline$\Delta$ Log_INOVA & -5.394209 & -3.646342 & Stationary \\
\hline Log_PUBDE & -0.338757 & -3.639407 & Non-stationary \\
\hline$\Delta$ Log_PUBDE & -5.255153 & -3.646342 & Stationary \\
\hline Log_INCOM & -3.193178 & -3.639407 & Non-stationary \\
\hline$\Delta$ Log_INCOM & -4.152397 & -3.646342 & Stationary \\
\hline
\end{tabular}

Note: Test of unit root conducted with intercept.

Source: Own study.

Table 4 shows that the test for stationary of these variables is done using the ADF test. The implication of non-stationarity of the variables in levels means standard regression analysis may produce spurious results. Generally, most series are made stationary by differencing the data in the first instance. The study variables, though integrated of different orders, are thus estimated without generating spurious results.

\section{Co-Integration Test Results}

Co-integration represents the tendency of variables to co-integrate together over time, implying the existence of a long-run relationship. To test for co-integration, the ADF test of unit root is conducted on the residuals of the various equations under study estimated in their levels. The study also employed the Johansen multivariate co-integration technique to confirm the existence of co-integration among these variables included in the models. The result is shown in Table 5. The result of the Johansen co-integration test is shown in Table 5. The result represents the tendency of variables to co-integrate over time, implying the existence of a long-run relationship between HUMAN, LABEF, INNOV, PUBDE, and INCOM.

Table 5. Results of Johansen co-integration test of model

\begin{tabular}{|l|c|c|c|}
\hline \multicolumn{3}{|c|}{ Series: HUMAN LABEF INOVA PUBDE INCOM } \\
\hline $\begin{array}{l}\text { Hypothesized Number of Co- } \\
\text { integrating Equations }\end{array}$ & Trace Statistic & $\begin{array}{c}\text { Critical Value at } \\
\mathbf{0 . 0 5}\end{array}$ & Prob.*** \\
\hline None & 94.27640 & 69.81889 & 0.0002 \\
\hline At most 1* & 58.29904 & 47.85613 & 0.0039 \\
\hline At most 2 & 29.20936 & 29.79707 & 0.0583 \\
\hline $\begin{array}{l}\text { Hypothesized Number of Co- } \\
\text { integrating Equations }\end{array}$ & $\begin{array}{c}\text { Max-Eigen } \\
\text { Statistic }\end{array}$ & $\begin{array}{c}\text { Critical Value at } \\
\mathbf{0 . 0 5}\end{array}$ & Prob.** \\
\hline None & 35.97736 & 33.87687 & 0.0277 \\
\hline At most 1* & 29.08968 & 27.58434 & 0.0318 \\
\hline At most 2 & 15.53430 & 21.13162 & 0.2532 \\
\hline
\end{tabular}

Note: *denotes rejection of the null hypothesis of no co-integration at the 5 percent Source: Own study. 
Table 5 indicates that variables converge to a long-run equilibrium. Both the trace statistic and Maximum Eigen tests reject the null hypothesis. The trace test statistic suggested at most one co-integrating vector. This means that HUMAN, LABEF, INOVA, PUBDE, and INCOM have long-run relationships or in the long run they move together while the Maximum Eigen test statistic also confirmed at most one co-integrating vector. This means that all five variables consisting of HUMAN, LABEF, INOVA, PUBDE, and INCOM are co-integrated or they have long-run association; in other words, in the long run they move together. In conclusion, the evidence of co-integration from both the trace statistic and Max-Eigen statistic cointegration tests indicate that they are indicating the same thing. That is, all five variables, HUMAN, LABEF, INOVA, PUBDE, and INCOM, are co-integrated; namely, they have a long-run relationship.

\section{Regression Model}

This study seeks to analyze the long-run association between fiscal policy and human capital by including four independent variables consisting of labor effectiveness (LABEF), Thailand's innovation (INOVA), public debt (PUBDE), and personal income (INCOM) in order to explore the real impact of the fiscal policy and personal income on the human capital and without relevant control variables. The data is done by the annual data covering 1985 to 2019 , a period of 35 years for each variable. The regression model is used to find out the results using a simple model on the fiscal policy, personal income, and human capital nexus. In the simple model, there is no control variable involved in the model specification. The simple model is a preliminary analysis of the association and its significance between fiscal policy, personal income, and human capital. The results of the longrun regression model is shown in Table 6.

Table 6. Model of regression long-run results

\begin{tabular}{|c|c|c|c|c|}
\hline \multicolumn{5}{|c|}{ Dependent variable: LHUMAN } \\
\hline Variables & Coefficient & Std. error & t-Statistic & Prob. \\
\hline \multicolumn{1}{|c|}{ C } & 2.278696 & 0.204051 & 11.16730 & 0.0000 \\
\hline LLABEF & 0.112254 & 0.049124 & 2.285131 & $0.0295^{* *}$ \\
\hline LINOVA & 0.149155 & 0.036250 & 4.114656 & $0.0003^{* * *}$ \\
\hline LPUBDE & -0.096374 & 0.033336 & -2.891015 & $0.0071^{* * *}$ \\
\hline \multicolumn{1}{|l|}{ LINCOM } & 0.819308 & 0.072405 & 11.31568 & $0.0000^{* * *}$ \\
\hline R-squared & 0.9888953 & & \\
\hline $\begin{array}{l}\text { Adj. } \\
\text { squared }\end{array}$ & 0.987480 & \\
\hline F-statistic & 657.3968 \\
\hline $\begin{array}{l}\text { Prob.(F- } \\
\text { statistic) }\end{array}$ & 0.000000 & \\
\hline Durbin-Watson statistic 1.477304 \\
\hline
\end{tabular}

Note: Significance at: $* * * 1, * * 5$, and $* 10$ percent respectively.

Source: Own study. 
Table 6 presents the long run of the regression model, and the model shows that approximately 98.8 percent of variations in human capital can be explained by these components. From the table, the first variable, labor effectiveness (LLABEF), dividing total education expenditure by the higher education students, is significant as the p-value of the variable is less than 5 percent level. Its positive coefficient of 0.112 means that the percentage rise in labor effectiveness leads to an approximately 0.11 percent increase in human capital in the long run. The positive coefficient of labor effectiveness is consistent with the a priori expectation of the study. This core finding is also consistent with the findings of Sun et al. (2020) that highly educational worker or labors' educational level is an important role of labor productivity in more developed areas. Moreover, Liu (2017) confirmed that the structure of the higher education system has positively generated to human capital and expanding productivity.

The second variable, Thailand's innovation (LINOVA), has a positive coefficient of 0.149 , which means that a percentage rise in Thailand's innovation is associated with about a 0.14 percent increase in the human capital in the long run. This finding confirms to the a priori expectation of this research regarding the connection between Thailand's innovation and human capital in this study. Moreover, this variable, Thailand's innovation, is significant as the p-value is less than the 1 percent level. The finding was supported by the existing distinguished research by Seclen-Luna et al. (2020) pointed out that the importance of labor capacity is adopting technologies and innovations as an implementation of modern production practices, revolving around composition on production, total quality management, and employee productivity of firms. And, Jin and Tao (2015) agree that government policy should emphasize economic structure through structural optimization and technology reform.

The third variable, public debt (LPUBDE), has a negative coefficient of 0.096 and statistically significant as the p-value is less than the 0.01 level, which means a percentage rise in the public debt leads to about a 0.09 percent decrease in human capital in the long run. This finding is not confirmed to the a priori expectation of this research regarding the relation between the public debt and human capital. The finding, however, is consistent with that of Eberhardt and Presbitero (2015), who suggest that the capacity of policy makers to manage level of public debt depends upon the performance of the country's economic policy. And Abubakar, and Mamman, (2020) examined the effect of public debt on economic growth into the short run and long run effect on the economic growth of OECD countries. They showed a positive short run effect and negative long run effect of public debt on the economic growth of OECD countries. Because risk management on public debt may influence both debt level and debt composition and to both the micro and macro country, developing framework both short and long term. On the other hand, Tahir et al. (2020) examined that human capital and public investment are positively associated with economic growth including that human capital accumulation for developing countries. 
The final variable, personal income (LINCOM), which is one of the most interesting variables, is statistically significant at 1 percent and its positive coefficient of 0.819 . It implies that a percentage rise in personal income is associated with 0.81 percent rise in human capital in the long run. This result is consistent with the a priori expectation of this research. The finding points out that personal income refers to individual labor performance and authority. Human capital was classified according to their employment authorities. This result is also consistent with interesting research on fiscal policy and personal income. One distinguished research supporting this finding, Gensowski (2018) investigates the effect of personality attributes and cognitive abilities on lifelong income. He concluded that cognitive abilities have significantly and positively on income increase and disposable income of people has increased due to income transfer by improving labor abilities.

To investigate the short-run association of the model, an ECM was formulated based on the identified long-run relationships. Error correction terms included in the model capture the speed of adjustment towards long-run equilibrium. The presence of co-integrating relationships in the long-run model implies that all terms in the ECM are stationary. The model is also used to analyze the relationship, and show effectively how the short-run impact of variables is related to the long-run equilibrium between them. The short-run regression results are shown in Table 7.

Table 7. Model of regression short-run results

\begin{tabular}{|l|c|c|c|c|}
\hline \multicolumn{5}{|c|}{ Dependent variable: LHUMAN } \\
\hline Variables & Coefficient & Std. error & t-Statistic & Prob. \\
\hline C & 0.168299 & 0.059962 & 2.806753 & 0.0109 \\
\hline D(LLABEF)(-1) & -0.093479 & 0.0988280 & -0.951147 & 0.6529 \\
\hline D(LLABEF)(-2) & -0.0799031 & 0.086188 & -0.916954 & 0.3701 \\
\hline D(LINOVA)(-1) & -0.121762 & 0.073508 & -1.656443 & 0.1132 \\
\hline D(LINOVA)(-2) & -0.023072 & 0.081072 & -0.284583 & 0.7789 \\
\hline D(LPUBDE)(-1) & -0.232859 & 0.118302 & -1.968335 & $0.0630^{*}$ \\
\hline D(LPUBDE)(-2) & -0.083161 & 0.107977 & -0.770178 & 0.4502 \\
\hline D(LINCOM)(-1) & -0.997929 & 0.548237 & -1.820252 & $0.0837^{*}$ \\
\hline D(LINCOM)(-2) & -0.533311 & 0.373835 & -1.426594 & 0.1691 \\
\hline \multicolumn{1}{|c|}{ ECM(-1) } & -1.192719 & 0.328789 & -3.627610 & $0.0017^{* * *}$ \\
\hline R-squared & 0.557119 & & \\
\hline Adj. R-squared & 0.313535 & 44.20340 & & \\
\hline Log likelihood & 2.287169 & & \\
\hline F-statistic & 0.052004 & \\
\hline Prob. (F-statistic) & Durbin-Watson statistic & 1.781395 & \\
\hline Dot Signficance at: &
\end{tabular}

Note: Significance at: $* * * 1, * * 5$, and $* 10$ percent respectively.

Source: From Author's Calculation

Table 7 summarized the short-run findings of the regression model. The coefficient of the error correction term is negative and significant, implying that a long run 
equilibrium or relationship exists between these variables. It means that the direction of causality runs interactively via the error correction term from labor effectiveness, Thailand's innovation, public debt, and personal income to human capital. Thus, we assumed that it may posit with the full adjustment of the deviation took over one year in Thailand.

Likewise, from the result, the first variable, public debt (PUBDE), has significance at 0.1 with a negative coefficient of 0.23 , which implies that all things being equal, a percentage rise in public debt at lag (1) is associated with a 0.23 percent decrease in human capital on holding other things constant in the short run. However, Armstrong, (2019) explained that public debt has a neutral effect on country's development that can help to develop an economy in the long run by improving the knowledge and skills of human capital in the country. This is premised upon the view that when the government borrows and channels the funds towards economic stimulating expenditure such as public investment. Hence, the trade-off between public debt and human capital involved for policy makers and the absorptive capacity of public debt definitely positive influence in the long-term country's development, this leads to an increase in economy including labor enhancement.

The second variable, a percentage change in personal income (INCOM) at lag (1), is associated with a 0.99 percent decrease in human capital on holding other things constant in the short run at 0.1 statistically significant level. But, in the expected sign of the predictor variable, personal income has positively impact on human capital in the long run. Kennedy et al. (2017) explained that accurate policy makers can manipulate rising income inequality by implementing measures that support and enhance on human capital accumulation given its long-run economic and sustainable development in the country. And, Gensowski (2018) concluded that cognitive abilities and personal abilities have significantly and positively on income increase according with previous long run finding.

The Durbin-Watson statistic becomes closed to 2. Its value is 1.78 , indicating that there is no serial correlation among these variables when estimating the ECM. The F-statistic indicates that fiscal policies consisted of labor effectiveness, Thailand's innovation, public debt, and personal income jointly determine the human capital in Thailand.

\section{Conclusion}

Following the results explained in the preceding section, the author empirically examined the impact of different types of fiscal policy, which consisted of labor effectiveness, Thailand's innovation, public debt, and personal income, on human capital in Thailand. The Engle-Granger co-integration model found that there is the existence of a long-term relationship between fiscal policy and human capital. The results found that change in these economic factors, labor effectiveness, Thailand's innovation, and personal income, has positively responded to human capital in 
Thailand in the long run with the statistical insignificance of coefficients. However, only public debt is statistically significant in the negative responds in the long run to human capital. It indicated that public policy is not governed to determine public investment properly in order to produce the economic sustainability of a country and also produced a crowding-out effect for human capital, resulting in reduced human capital. Because of this, public activities are not accurately profitable and cannot generate future optimal human capital development. A rapid increase in public debt without good governance into practice severely impedes highest public utility, widens budget deficits, and eventually leads to a mounting public debt crisis.

As a consequence, this not only crowds out private investment but also raises fiscal liability that will impede the proportion of investment budgets allocated to invest in several sectors especially in the education and innovation sectors in the future. Moreover, this may well endanger sustainable macroeconomic development in many ways and could create useless policy targets. However, a high level of public debt in Thailand is still important in order to various structure reform and fiscal imbalance. All in all, in a broader macroeconomic context for fiscal policy, policy makers should be struggling to ensure debt risk for managing the government's debt in order to raise economic development and human capital over the medium to long term of optimizing labor performance of industry's needs in Thailand. In addition, the estimation of ECM play to estimate the short run impact of the relevant variables. The result presents an ECM coefficient of -1.192. It is properly signed which means that the dependent variables are valid that is giving validity that the entire variables have a long run equilibrium relationship.

The study also found that public debt and personal income appear significant at 10 percent level in the short run, with an inverse effect estimation on human capital, although it is significant in the short run. This indicates that both public debt and personal income are the main factors of human capital in Thailand. This is consistent with the finding of Onafowora and Owoye, (2019) confirmed that domestic investment with good governance in to practice of public debt has positive effects on economic and labor development caused to job creation with full employment.

\section{Implications}

Due to the research results, the study attempted to explore the composition effect of fiscal policy and personal income on human capital in Thailand. It covered the period from 1985 to 2019 . There is a research application that can be found in this study. At this point, in order to ensure a comprehensive perspective on fiscal issues, education system could be changed and reformed the role to the making more effective on Thailand's education. It has to develop both schooling and teacher including recruitment of essentially skilled teachers such as using technological skill to be sufficient for the number of students and responding to industry needs in Thailand. Technology and online social media gradually play a crucial role in the 
new education reform. It can also adjust properly the most suitable learning system for learner to study at their own pace. In addition, new role of education system is just a facilitator in class and also monitoring accepted skills of business need in the future of country. This method helps diverse sets of knowledge to be high quality of labor especially on higher education students (in university) and correspond to the skill needed of next ages. The teacher should change their role from teaching to gearing and facilitating to student while the technology, new role education system, is brought in class and finally teacher will face more easy and effective job with full student competence that should be worthwhile to move forward human capital in the short run and long run of country.

This is consistent with the finding that the strength of higher education level of workers as an essential country's development goal has been governed by public policy (Sun et al., 2020). In sum, policy makers must use effectively fiscal policy activities to certainly build economic sustainability. It means creating long-term sustainable value, both human and material. If fiscal policy especially on public debt did not motivate the core economic sustainable needs, the borrowing may have crowded out effect. In practice, government expenditure is spent matters to enhance business confidence and avoid leakages risks and policy organization should also be desired to move towards and examine some form of a medium to final term fiscal framework whereby planning and policy are certainly conducted explicitly fiscal activity on a rolling multiple year lead to economic sustainability both and optimal growth rate and human capital accumulation in Thailand.

\section{References:}

Abubakar, A.B., Mamman, S.O. 2020. Permanent and transitory effect of public debt on economic growth. Journal of Economic Studies.

Armstrong, P. 2019. Keynes's view of deficits and functional finance: a Modern Monetary Theory perspective. International Review of Applied Economics, 33(2), 241-253.

Dickey, D.A., Fuller, W.A. 1981. Likelihood ratio statistics for autoregressive time series with a unit root. Econometrica: journal of the Econometric Society, 1057-1072.

Dimov, D. 2017. Towards a qualitative understanding of human capital in entrepreneurship research. International Journal of Entrepreneurial Behavior \& Research.

Eberhardt, M., Presbitero, A.F. 2015. Public debt and growth: Heterogeneity and nonlinearity. Journal of International Economics, 97(1), 45-58.

Eclac, U. 2015. Latin America and the Caribbean and China: Towards a New Era in Economic Cooperation. Engle, R.F., Granger, C.W. (1987). Co-integration and error correction: representation, estimation, and testing. Econometrica: Journal of the Econometric Society, 251-276.

Engle, R.F., Granger, C.W. 1987. Co-integration and error correction: representation, estimation, and testing. Econometrica: Journal of the Econometric Society, 251-276.

Gan, C.H., Zheng, R.G. 2011. The impact of industrial structure changes on economic growth and fluctuation in China. Journal of Economic Research, 5, 4-16.

Gensowski, M. 2018. Personality, IQ, and lifetime earnings. Labour Economics, 
$51,170-183$.

Goldin, C. 2016. Human Capital. Diebolt, C., Haupert, M. (Eds.). Handbook of Cliometrics.

Huang, Z.G., Liu, X.H. 2015. China's economic growth path selection under the new normal. News of Economics, 9, 51-62.

Jin, T., Tao, X.Y. 2015. Analysis and comparison of the phased motivation of China's sustained economic growth. The Journal of Quantitative and Technical Economics, 11, 74-89.

Kennedy, T., Smyth, R., Valadkhani, A., Chen, G. 2017. Does income inequality hinder economic growth? New evidence using Australian taxation statistics. Economic Modelling, 65(C), 119-128.

Liu, L. 2017. Three Papers in Economic growth and Inequality. The Structure of Higher Education System and Economic growth, 49-54.

Ministry of Education. 2017. Thai Education in Brief. Education as a Spearhead to Break through the Middle Income Trap, 1-4.

Mthanti, T., Ojah, K. 2017. Entrepreneurial orientation (EO): measurement and policy implications of entrepreneurship at the macroeconomic level. Research Policy, 46(4), 724-739.

Office of the National Economic and Social Development Council. 2019. Gross Domestic Product: Q2/2019, 2-20.

Office of the National Economic and Social Development Council. 2019. The Twelfth National Economic and Social Development Plan 2017-2021, 2-87.

Onafowora, O., Owoye, O. 2019. Public debt, foreign direct investment and economicgrowth dynamics. International Journal of Emerging Markets.

Rong, Z. 2020. Productivity, public capital, and socialism with Chinese characteristics-A critique of the doctrine of incompatibility between capital and public ownership. China Political Economy.

Sandrine, M. 2015. Education in Thailand: When Economic Growth is no longer enough. London Review of Education, 13(3). 79-91.

Seclen-Luna, J.P., Opazo-Basáez, M., Narvaiza, L., Fernández, P.J.M. 2020. Assessing the effects of human capital composition, innovation portfolio and size on manufacturing firm performance. Competitiveness Review: An International Business Journal.

Sun, X., Li, H., Ghosal, V. 2020. Firm-level human capital and innovation: evidence from China. China Economic Review, 59, 101388.

Tahir, M., Hayat, A., Rashid, K., Afridi, M.A., Tariq, Y.B. 2020. Human capital and economic growth in OECD countries: some new insights. Journal of Economic and Administrative Sciences.

Teles, V.K., Mussolini, C.C. 2014. Public debt and the limits of fiscal policy to increase economic growth. European Economic Review, 66, 1-15.

UNDP. 2019. Inequalities in Human Development in the $21^{\text {st }}$ Century. Human Development Report 2019, 1 -10.

Usman, R.D., Wanjuu, L.Z. 2015. Government expending on education and economic growth: Evidence from Nigeria. Paper presented at 4thInternational Conference, Faculty of Social and Management Sciences. Kaduna State University, 16-17 June.

Wooldridge, J.M. 2016. Introductory econometrics: A modern approach. Nelson Education.

Yu, Z., Zhu, N., Baležentis, T. 2017. Impact of public education and regional economic growth in China: A shadow-price perspective. Sustainability, 9(8), 1333.

Zhao, Z.Y. 2014. Development of innovation driven: From demand side to supply side. China Soft Science, 8, 1-5. 